Vol.5, No.1, April 2019

Doi: $10.24198 /$ cosmogov.v2i2.xxxxx

\title{
ANALISIS IMPLEMENTASI KEBIJAKAN KERJASAMA PENGELOLAAN PARKIR DALAM MEWUJUDKAN GOOD GOVERNANCE PENGELOLAAN PARKIR DI KOTA SOLOK
}

\author{
Riko Budiawan ${ }^{1}$ \\ Afrizal $^{2}$ \\ Najmuddin $^{3}$ \\ ${ }^{1} J u r u s a n$ Pembangunan Wilayah dan Pedesaan, Universitas Andalas \\ ${ }^{2}$ Jurusan Sosiologi, Fakultas Ilmu Sosial dan Politik, Universitas Andalas \\ ${ }^{3}$ Jurusan Komunikasi, Fakultas Hukum, Universitas Andalas \\ Email: rikobudiawan665@gmail.com
}

\begin{abstract}
ABSTRAK
Penelitian ini menganalisis implementasi kebijakan kerjasama pengelolaan parkir di Kota Solok yang beberapa tahun belakang pengelolaan dan pelayanannya menjadi bahan pembicaraan yang tidak pernah selesai di tengah masyarakat maupun media lokal. Penelitian ini difokuskan pada deskripsi analisis implementasi kebijakan kerja sama pengelolaan parkir yakni Perwako Solok No. 7 tahun 2015 tentang Tata cara Pengelolaan Lahan Parkir di Tepi Jalan Umum dan Perwako Solok No. 8 tahun 2015 tentang Tata cara Pengelolaan Lahan Parkir Tempat Khusus Parkir dalam rangka mewujudkan Good Governance pengelolaan parkir. Adapun indikator Good Governance yang digunakan sebagai fokus penelitian adalah Partisipasi, Penegakan Hukum, Transparansi, Efektifitas dan Efesiensi dan Akuntabilitas. Penelitian ini juga mendeskripsikan faktor-faktor yang menghambat keberhasilan implementasi Kebijakan Kerja sama Pengelolaan Parkir di Kota Solok. Lokasi penelitian yang dipilih adalah lingkungan Pemerintah Daerah Kota Solok, dengan menggunakan metoda penelitian kualitatif dengan sumber data wawancara informan, dokumen, rekaman dan observasi. Hasil penelitian ini menunjukkan bagaimana lemahnya implementasi kebijakan pengelolaan parkir dalam mewujudkan Good Governance Pengelolaan parkir di Kota Solok.
\end{abstract}

Kata kunci: implementasi; kebijakan publik; good governance, kota solok

\section{ABSTRACT}

This research analyzes the implementation of the policy of parking management cooperation in Solok City which some years behind the management and service becomes the talks that never finished in the middle of society and local media. This 
Vol.5, No.1, April 2019

Doi: $10.24198 /$ cosmogov.v2i2.xxxxx

research is focused on the description of policy implementation analysis of parking management cooperation, namely Solok Mayor Regulation No. 7 of 2015 on the Procedures of Parking Land Management at Public Road and Solok Mayor Regulation no. 8 of 2015 on the Procedures of Parking Land Management Parking Special Places in order to realize Good Governance of parking management. The Good Governance indicators used as the focus of research are Participation, Rule of law, Transparency, Effectiveness and Efficiency and Accountability. This study also describes the factors that hampered the successful implementation of the Parking Management Cooperation Policy in Kota Solok. The selected research location is Solok City Government environment, using qualitative research method with source of informant interview data, document, recording and observation. The results of this research show how weak implementation of parking management policies in realizing Good Governance Parking Management in Solok City.

Keywords: implementation; public policy; good governance; solok city

\section{PENDAHULUAN}

Semenjak diberlakukannya pada tahun 1999 yang diperbaharui menjadi undang-undang No 32 tentang 2004 tentang Pemerintah daerah dan terakhir menjadi undang - undang No 23 tentang 2014 tentang Pemerintah daerah, otonomi daerah ditujukan mendekatkan pelayanan pemerintah kepada rakyat.

Sumber daya publik milik bersama penting bagi pemerintah, swasta dan masyarakat. Pengelolaan sumber daya publik milik bersamaperlumenjadi perhatian khusus bagi pemerintah dalam upaya untuk memenuhi ketersediaan sarana prasarana dasar dan peningkatan pelayanan kebutuhan dasar masyarakat. Salah satu sumberdaya publik lokal yang perlu dikelola secara efektif adalah tempat parkir di perkotaan. Tempat parkir sangat berperan penting dalam upaya menjaga stabilitas pembangunan di perkotaan. Mengingat semakin tingginya angka pertumbuhan penduduk yang diiringi semakin berkembangnya pusat aktivitas ekonomi dan bisnis serta berimbas pada bertambah pesatnya jumlah kendaraan terutama kendaraan pribadi sebagai akibat tingginya penjualan kendaraan bermotor. Seiring dengan hal tersebut, kebutuhan akan ruang parkir semakin tidak terkendali meliputi penggunaan fasilitas umum seperti badan jalan sehingga menimbulkan kemacetan lalu lintas dan akses keluar masuk kendaraan. Kondisi ini berdampak pada meningkatnya tingkat kecelakaan lalu lintas, polusi udara, menghilangnya ruang publik dan menurunkan potensi ekonomi. (GIZ SUTIP,2015)

Kota Solok merupakan salah satu kota yang lokasinya sangat strategis, terletak di persimpangan jalan antara provinsi dan antara kabupaten/kota. 
Vol.5, No.1, April 2019

Doi: $10.24198 /$ cosmogov.v2i2.xxxxx

Kota ini merupakan titik persimpangan arah selatan jalur lintas dari Provinsi Lampung, Provinsi Sumatera Selatan dan

Provinsi Jambimenuju kota

Padang sebagai ibu kota Provinsi Sumatera Barat yang jaraknya hanya sekitar $64 \mathrm{Km}$ saja. Bila ke arah utara menuju kota Bukittinggi yang berjarak sekitar $71 \mathrm{Km}$ untuk menuju kawasan Sumatera Bagian Utara.

Beberapa tahun belakang, persoalan pengelolaan dan pelayanan parkir di kota Solok menjadi bahan pembicaraan yang tidak pernah selesai di tengah masyarakat maupun media lokal, kondisi penataan parkir yang belum baik terlihat di titik keramaian kawasan kota terutama tepi jalan umum, pusat-pusat pertokoan, hiburan, pasar dan pusat keramaian lainnya. Lokasi parkir liar di Kota Solok sangat mudah didapatkan, bahkan ruang kosong di tepi jalan pun dijadikan lahan parkir. Petugas parkir tanpa identitas dan seragam berkeliaran disepanjang jalan utama kota. Ditinjau dari sisi pendapatan, penerimaan dari sektor parkir bagi pemerintah daerah juga dinilai belum optimal. Hal ini dikarenakan penerimaan restribusi daerah yang diperoleh di parkir belum sesuai target.

Untuk menyelesaikan persoalan pelayanan dan pengelolaan parkir, Pemerintah Kota Solok membuat terobosan dengan menerbitkan Perwako Solok No. 7 tahun 2015 tentang Tata cara Pengelolaan Lahan Parkir di Tepi Jalan Umum dan Perwako Solok No. 8 tahun 2015 tentang Tata cara Pengelolaan Lahan Parkir tempat khusus parkir. Kebijakan tersebut menekankan pada upaya kerjasama pemerintah daerah dengan pihak ketiga dalam pengelolaan parkir. Kerja sama tersebut dapat dilakukan dengan cara mekanisme tender atau lelang atau penunjukan langsung.

Namun dalam pelaksanaannya, implementasi kebijakan tersebut sepertinya gagal menghasilkan dampak perubahan terhadap ketertiban pengelolaan dan peningkatan pendapatan restribusi parkir di Kota Solok. Devolusi kewenangan ini justru tidak mampu menyelesaikan permasalahan terkait pelayanan parkir tersebut. Salah satunya, berdasarkan informasi media online kritisnews.com tanggal 19 desember 2016 ditemukan adanya laporan pelanggaran Peraturan Daerah (Perda) nomor 2 tahun 2013 tentang Perubahan atas Perda nomor 3 tahun 2012, tentang Retribusi Jasa Usaha. Pengendara yang memarkirkan kendaraan dilokasi tersebut dipungut biaya parkir sebesar Rp. 2.000,00 bagi kendaraan roda dua. Sementara, bagi kendaraan roda empat, setiap kali parkir dikenakan Rp. 3000 - Rp.4.000. Tarif parkir yang dikenakan tersebut dinilai melenceng dari tarif yang ditetapkan dalam aturan. Sekaitan dengan itu telah bermunculan parkir 
Vol.5, No.1, April 2019

Doi: $10.24198 /$ cosmogov.v2i2.xxxxx

liar yang dikelola oleh oknum aparat pemerintah kota.

Sehubungan dengan kegagalan pemerintah daerah dalam meghasilkan dampak perubahan pelayanan dan pengelolaan parkir di Kota Solok, penting bagi penulis menganalisis lebih dalam bagaimana implementasi kebijakan kerja sama pengelolaan parkir yang telah dilaksanakan dan penyebab kegagalannya dalam upaya mewujudkan Good Governance pengelolaan parkir di Kota Solok.

Terkait fenomena pemecahan permasalahan pelayanan dan pengelolaan parkir telah menjadi perhatian para peneliti sebelumnya. Aditya Wisnu Priambodo (2012-2013) melakukan penelitian yang memfokuskan pada Analisis pengelolaan parkir di Tepi Jalan Umum di kota Semarang. Novayanti SR, Gita Susanti (2012-2013) memfokuskan penelitian terkait Kerjasama Publik dan Swasta dalam Pengelolaan Parkir di RSUP Dr Wahidin Sudirohusodo Kota Makasar. Penelitian Ilmiati Andril, Ardi Abbas dan Surya Prahara (2014) terfokus pada analisis konflik pengelolaan parkir liar di Kecamatan Pantai Purus Padang Barat, Kota Padang. Sebagai pelengkap penelitian tentang pelayanan dan pengelolaan parkir, peneliti mencoba mengkaji tentang Implementasi Kebijakan Kerjasama Pengelolaan Parkir untuk Mewujudkan Good Governance Pengelolaan Parkirdi Kota
Solok.Penelitian akan menjawab pertanyaan-pertanyaan berikut ini.

1. Bagaimanakah Implementasi Kebijakan Kerja sama Pengelolaan Parkir dalam Mewujudkan Good Governance Pengelolaan Parkir di Kota Solok?

2. Faktor-faktor apa saja yang menghambat keberhasilan Implementasi Kebijakan Kerja sama Pengelolaan Parkir dalam upaya mewujudkan Good Governance Pengelolaan Parkir di Kota Solok?

Dalam mewujudkan pemerintahan yang baik (Good Governance), kerjasama antara pemerintah dan lembaga non pemerintah dalam pelayanan publik diharapkan lebih dapat dimaksimalkan karena permasalahan publik sekarang ini terlihat lebih kompleks dan strategis. Sinergi antara pemerintah, swasta dan masyarakat menjadi solusi penyelesaian persoalan tentang perparkiran. Untuk merespon isu tersebut pemerintah berkewajiban mereposisi perannya sebagai alokatif, distributif, regulatif, dan stabilatif. Tugas pemerintah hanya sebagai pendorong dan fasilitator sektor swasta/masyarakat dalam pelayanan public. Tentunya sesuai dengan pendapat (LAN; 2000,8) yang mengemukakan bahwa Good Governance adalah pemerintahan negara dilaksanakan secara solid yang 
Vol.5, No.1, April 2019

Doi: $10.24198 /$ cosmogov.v2i2.xxxxx

bertanggung jawab, serta efisien dan efektif dengan menjaga sinergisitas interaksi yang positif diantara domaindomain negara, sektor swasta dan masyarakat.

Hubungan diantara ketiga unsur utama (domain) tersebut digambarkan sebagai berikut:

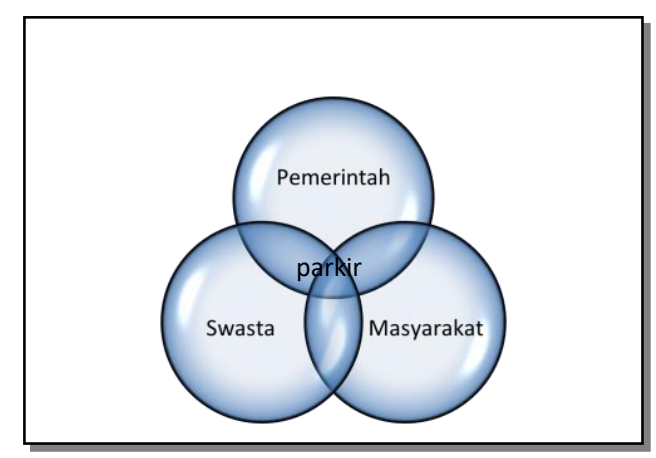

Sumber: Hasil Olahan penulis dari teori Good Governance dan kerja sama pengelolaan parkir

Grindle dalam Nirmala Mustika Dewi (2015) menyatakan bahwa Content of Policy (isi kebijakan) dan Context of Implementation (konteks implementasi) sangat menentukan keberhasilan implementasi kebijakan. Isi kebijakan yang dapat mempengaruhi implementasi yaitu:

1. Kepentingan dipengaruhi oleh program.

Pencapaian efesiensi dan efektifitas dari setiap program yang dilaksanakan akan dipermudah jika mengetahui kepentingan kelompok sasaran

2. Bentuk mamfaat yang diperoleh.
Dukungan dari kelompok sasaran atau masyarakat akan lebih mudah didapatkan jika implementasi kebijakan memiliki dampak kolektif utuk banyak orang.

3. Skala perubahan yang diharapkan.

Skala yang jelas terhadap perubahan yang diharapkan.

4. Posisi pengambil kebijakan.

Semaikin luas posisi pengambil kebijakan akan semakin sulit pula implementasinya. Seringkali terjadi pada peristiwa atau kejadian dalam ruang lingkup banyak instansi.

5. Pelaksana program.

Adanya pelaksana kebijakan yang kompeten sangat penting dalam menjalankan suatu kebijakan atau program demi keberhasilan kebijakan itu sendiri

6. Sumber daya yang disediakan Untuk mempermudah pengimplementasian kebijakan diperlukan sumberdaya berupa tenaga kerja, keahlian, dana, sarana, dll.

Selanjutnya Grindle dalam Nirmala Mustika Dewi (2015) menjelaskan Context of Implementation, Tingkat keberhasilan suatu implementasi kebijakan dipengaruhi oleh siapa dan dimana kebijakan tersebut dimplementasikan., implementator menjadi figur penting 
Vol.5, No.1, April 2019

Doi: $10.24198 /$ cosmogov.v2i2.xxxxx

dalam keberhasilan implementasi kebijakan. Menurut Grindle Konteks implementasi yang mempengaruhi implementasi adalah:

1. Kepentingan, kekuasaan, dan strategi aktor yang terlibat. Untuk lancarnya pelaksanaan implementasi kebijakan perlu andanya pertimbangan kepentingan, kekuasaan dan strategi oleh pelaksana kebijakan.

2. Karakteristik lembaga dan penguasa. Strategi penyelesaian konflik menjadi petunjuk tak langsung mengenai ciri-ciri penguasa atau lembaga yang menjadi implementor mengenai keberpihakan

penguasa/lembaga pelaksana maupun mengenai gaya kepemimpinan terhadap konflik kepentingan dalam memperoleh sumber daya, dan respon dari masyarakat maupun elit dalam interaksinya.

3. Kepatuhan dan daya tanggap pelaksana. Kepekaan Implementor atau pelaksana program terhadap kebutuhan kelompok sasarannya dengan tujuan keberhasilan suatu program dan dukungan dari kelompok sasaran.

Dwiyanto (1996: 19-20) bahwa mengemukakan faktor -faktor keberhasilan pengembangan kemitraan pemerintah dan swasta dalam pelayanan publik yaitu:

1. Penekanan kemitraan pada coproduction dan coprovision dapat berlangsung efektif yang disertai perubahan sikap dan orientasi pejabat birokrasi pemerintah;

2. Adanya fasilitas oleh pemerintah untuk pengembangan sektor swasta;

3. pengoptimalan peran swasta organisasi voluntir dan perusahaan dalam oprasional pelayanan publik dan pengurangan kterlibatan pemerintah.

4. Transparansi dan kterbukaan pengalihan peran pemerintah kepada swasta;

5. Adanya perbaikan efektifitas kontrol birokratik dan politik terhadap pelimpahan kekuasaan terhadap sektor swasta.

\section{METODE PENELITIAN}

Penelitian ini difokuskan Deskripsi analisis implementasi Kebijakan kerja sama pengelolaan parker yakni Perwako Solok No. 7 tahun 2015 tentang Tata Cara Pengelolaan Lahan Parkir di Tepi Jalan Umum dan Perwako Solok No. 8 tahun 2015 tentang Tata Cara Pengelolaan Lahan Parkir Tempat Khusus Parkir dalam rangka mewujudkan Good Governance pengelolaan parkir. 
Vol.5, No.1, April 2019

Doi: $10.24198 /$ cosmogov.v2i2.xxxxx

Sebagaimana yang dikemukakan Muhadjir (2000), pada penelitian kualitatif lazimnya dilaksanakan oleh pelaku tunggal (lone ranger). Dalam kaitan ini Guba (ibid) mengungkapkan bahwa salah satu karakteristik penelitian kualitatif adalah penggunaan "human instrument", yangmenuntut agar diri sendiri atau orang lain menjadi instrument pengumpul data, karena kemampuannya menyesuaikan diri dengan berbagai realitas. Namun demikian, dalam penelitian ini, peneliti membutuhkan pedoman wawancara serta sarana dokumentasi. Instrumen disusun berdasarkan fokus penelitian yang telah dikemukakan sebelumnya.

Sumber data dalam kegiatan penelitian ini adalah:

1. Orang (informan) yang berkaitan dengan data penelitian, objeknya antara lain sebagai informan adalah: Dinas Perhubungan, Dinas Perdagangan Koperasi dan UKM, DPRD, dinas dan instansi terkait, pihak pengelola yaitu swasta atau kelompok organisasi masyarakat di Kota Solok, petugas parkir dan pihak-pihak yang terkait (Stakeholder) yang relevan dalam penelitian ini yang berada di Kota Solok.

2. Peristiwa/situasi, yaitu kejadian yang sedang atau telah terjadi dan relevan dengan fokus penelitian.
3. Dokumen, berbagai data tertulis atau dokumentasi yang relevan dengan fokus penelitian.

Dalam penelitian kualitatif, jumlah sampel atau informan tidak ditentukan terlebih dahulu karena dalam proses pengumpulan data bila tidak ditemukan variasi informasi, maka peneliti tidak perlu lagi melanjutkan dengan mencari informasi baru sampai hasil yang diperoleh sama dengan informasi sebelumnya. Jadi jumlah sampel bisa saja sedikit tetapi juga bisa banyak, hal ini tergantung dari: tepat tidaknya pemilihan informan kunci, kompleksitas dan keragaman fenomena sosial yang diteliti. Oleh sebab itu yang bisa ditentukan hanya sampel awal saja. Dalam proses pengumpulan data jika tidak ditemukan lagi variasi informasi/telah mencapai titik jenuh, maka peneliti tidak lagi mencari informasi baru, dan proses pengumpulan informasi dianggap selesai/telah cukup. Dalam penelitian kualitatif, ada tiga tahap pemilihan informan yang baik jika kita memakai teknik snowball sampling dalam pengumpulan informasi antara lain:

1. Pemilihan sampel awal, yakni berupaya menemukan informan awal untuk diwawancarai.

2. Pemilihan informan lanjutan, guna memperluas deskripsi informasi dan melacak variasi informasi yang mungkin ada.

3. Menghentikan pemilihan informan lanjutan, bilamana 
Vol.5, No.1, April 2019

Doi: $10.24198 /$ cosmogov.v2i2.xxxxx

sudah tidak ditemukan lagi variasi informasi.

Di lapangan untuk menemui informan peneliti bebas melakukan wawancara, baik pagi maupun siang harinya, begitu juga tempatnya sesuai dengan situs penelitian. Umumnya wawancara dilakukan di kantor ataupun di rumah informan sehinggan bisa dilakukan observasi langsung di lapangan. Pemakaian bahasa Indonesia telah disepakati agar tercipta hubungan yang akrab dengan informan, sehingga mudah dimengerti kedua belah pihak, agar terjadi komunikasi dua arah dengan lancar.

Teknik analisis data yang digunakan seperti yang dikembangkan oleh Miles \& Huberman (1992) yakni analisis model interaktif (interactive model of analysis) meliputii tiga komponen analisis berupa:

1. Reduksi data (reduction data), yakni uraian atau laporan yang lengkap dan terinci yang diperoleh dilokasi penelitian.

2. Sajian data (data display), yakni bagian-bagian tertentu dari penelitian atau gambaran secara keseluruhan

3. Penarikan kesimpulan (conclusion drawing), yakni verifikasi secara berkelanjutan selama proses penelitian berlangsung, yaitu sejak awal memasuki lokasi dan proses pengumpulan data penelitian.

\section{HASIL DAN PEMBAHASAN Analisis Implementasi Kebijakan Kerjasama Pengelolaan Parkir Dengan Pendekatan Teori Good Governance}

Berdasarkan hasil penelitian penulis terhadap analisis implementasi kebijakan kerjasama pengelolaan parkir dalam mewujudkan Good Governance pengelolaan parkir di Kota Solok, ditemukan beberapa persoalan yang mendasar antara lain:

\section{a. Kuatnya dominasi masyarakat setempat terhadap penguasaan dan akses pengelolaan sumber daya parkir di Kota Solok}

Pada pengelolaan parkir di Tepi jalan umum, sejak diberlakukannya Perwako No.7 tahun 2105 tentang kerjasama pengelolaan parkir di Tepi Jalan Umum, selama 3 (tiga) tahun berturut-turut dilakukan oleh masyarakat perorangan. Masyarakat perorangan ditunjuk sebagai pengelola parkir tidak memiliki legalitas hukum. Ketentuan syarat yang tercantum pada peraturan Walikota terhadap pihak pengelola bukan menjadi hambatan bagi warga setempat untuk dapat berkontribusi dalam pengelolaan parkir di Kota Solok.

Ada pun riwayat pengelolaan parkir di tepi jalan umum di Kota Solok adalah sebagai berikut: 
Vol.5, No.1, April 2019

Doi: 10.24198/cosmogov.v2i2.xxxxx

\begin{tabular}{|c|c|c|c|c|}
\hline NO & TAHUN & LOKASI & PENGELOLA & KET \\
\hline \multirow[t]{13}{*}{1.} & \multirow{13}{*}{$\begin{array}{l}2016,2017 \text { dan } \\
2018\end{array}$} & Rumah Makan Roda Baru & David Darlen & Masyarakat \\
\hline & & Sinar Listrik & David Darlen & Masyarakat \\
\hline & & Depan Toko cemerlang & David Darlen & Masyarakat \\
\hline & & Ex. Toko Mini & Junairi Nursali & Masyarakat \\
\hline & & Ex. Lapas I & Junairi Nursali & Masyarakat \\
\hline & & Ex. Lapas II & Junairi Nursali & Masyarakat \\
\hline & & $\begin{array}{l}\text { Ex. Pemberhentian } \text { Bendi } \\
\text { Simpang Rumbio }\end{array}$ & Syahrial & Masyarakat \\
\hline & & Bundo kanduang Barat & David Darlen & Masyarakat \\
\hline & & Solinda & Arni suyoto & Masyarakat \\
\hline & & Bundo Kanduang Timur & Maiyusril & Masyarakat \\
\hline & & Depan Win Jaya & Yulizar & Masyarakat \\
\hline & & Pangkas Rambut Berok & Yulizar & Masyarakat \\
\hline & & Kosmetik Ananda & Dedi Kartika & Masyarakat \\
\hline
\end{tabular}

Tabel 1.2 Riwayat Pengelolaan Parkir Tepi Jalan Umum Kota Solok Sumber: Olahan dari Laporan Dinas Perhubungan Kota Solok Tahun 2016, 2017dan 2018. 
Vol.5, No.1, April 2019

Doi: $10.24198 /$ cosmogov.v2i2.xxxxx

Menyoroti kemampuan akses warga tempatan terhadap pengelolaan parkir dikarenakan pola hubungan politik yang diperankan warga dengan pimpinan dan pejabat daerah.

Dorongan politik balas budi menjadikan warga tempatan menjadi aktor yang dominan terhadap pengelolaan sumber daya parkir di kota Solok.

Sedangkan pada kerjasama pengelolaan parkir di tempat khusus parkir, setelah diberlakukannya Perwako No.8 tahun 2105 tentang kerjasama pengelolaan parkir di tempat khusus parkir, awalnya kerjasama dilakukan dengan melibatkan pihak perusahaan, secara tiba-tiba tahun berikutnya kerjasama berubah kepada pihak masyarakat perorangan, sama halnya dengan pengelolaan parkir ditepi jalan umum, adapun riwayat penggantian kerjasama pengelolaan di tempat Khusus Parkir dapat dilihat pada tabel berikut:

\begin{tabular}{|c|c|c|c|c|}
\hline $\mathrm{NO}$ & TAHUN & LOKASI & PENGELOLA & KET \\
\hline 1. & 2016 & $\begin{array}{l}\text { 1. Blok VII Tahap III } \\
\text { 2. Pos Satpam Timur } \\
\text { 3. Pos Satpam Barat } \\
\text { 4. Pelataran pasar Modern }\end{array}$ & $\begin{array}{l}\text { CV. Jasa } \\
\text { Metro } \\
\text { CV. Wijaya } \\
\text { Kusuma } \\
\text { Cv. Annisa } \\
\text { Kontraktor } \\
\text { Cv. Lima Pilar }\end{array}$ & $\begin{array}{l}\text { Swasta } \\
\text { Swasta } \\
\text { Swasta } \\
\text { Swasta }\end{array}$ \\
\hline 2. & 2017 & $\begin{array}{l}\text { 1. Blok VII Tahap III Kanan } \\
\text { 2. Blok VII Tahap III Kiri } \\
\text { 3. Pos Satpam Timur } \\
\text { 4. Pos Satpam Barat } \\
\text { 5. Pelataran pasar Modern } \\
\text { 6. Depan H. Damrah (Ex. } \\
\text { Penampungan) } \\
\text { 7. Depan H. Damrah } \\
\text { 8. Tahap IV Sebelah kanan } \\
\text { 9. Tahap IV Sebelah Kiri } \\
\text { 10. Depan Los Daging dan Ikan }\end{array}$ & $\begin{array}{l}\text { Devi Oktavia } \\
\text { Hengky } \\
\text { Irawan } \\
\text { Yulhendri } \\
\text { Firdaus } \\
\text { Arijal } \\
\text { Joni Edwar }\end{array}$ & $\begin{array}{l}\text { Masyarakat } \\
\text { Masyarakat } \\
\text { Masyarakat } \\
\text { Masyarakat } \\
\text { Masyarakat } \\
\text { Masyarakat }\end{array}$ \\
\hline
\end{tabular}


Vol.5, No.1, April 2019

Doi: $10.24198 /$ cosmogov.v2i2.xxxxx

\begin{tabular}{|c|c|c|c|}
\hline & & $\begin{array}{l}\text { Armon A } \\
\text { Syafriadi } \\
\text { Sri anita Refni } \\
\text { Afrizal }\end{array}$ & $\begin{array}{l}\text { Masyarakat } \\
\text { Masyarakat } \\
\text { Masyarakat } \\
\text { Masyarakat }\end{array}$ \\
\hline 2018 & $\begin{array}{l}\text { 1. Blok VII Tahap III Kanan } \\
\text { 2. Blok VII Tahap III Kiri } \\
\text { 3. Pos Satpam Timur } \\
\text { 4. Pos Satpam Barat } \\
\text { 5. Pelataran pasar Modern } \\
\text { 6. Depan H. Damrah (Ex. } \\
\text { Penampungan) } \\
\text { 7. Depan H. Damrah } \\
\text { 8. Tahap IV Sebelah kanan } \\
\text { 9. Tahap IV Sebelah Kiri } \\
\text { 10. Depan Los Daging dan Ikan }\end{array}$ & $\begin{array}{l}\text { Devi Oktavia } \\
\text { Hengky } \\
\text { Irawan } \\
\text { Yulhendri } \\
\text { Firdaus } \\
\text { Arijal } \\
\text { Joni Edwar } \\
\text { Armon A } \\
\text { Syafriadi } \\
\text { Sri anita Refni } \\
\text { Afrizal }\end{array}$ & $\begin{array}{l}\text { Masyarakat } \\
\text { Masyarakat } \\
\text { Masyarakat } \\
\text { Masyarakat } \\
\text { Masyarakat } \\
\text { Masyaraka }\end{array}$ \\
\hline
\end{tabular}

Tabel 1.2 Riwayat Pengelolaan Parkir Tepi Jalan Umum Kota Solok

Sumber: Olahan dari Laporan Dinas Perindag Kota Solok Tahun 2016, 2017, dan 2018. 
Vol.5, No.1, April 2019

Doi: $10.24198 / \operatorname{cosmogov} . v 2 \mathrm{i} 2 . x x x x x$

Masyarakat perorangan yang menjadi pengelola parkir secara ketentuan aturan tidak memenuhi syarat sebagai pihak pengelola yang berbadan hukum. Ketidakkonsistenan pengelolaan parkir ditandai dengan adanya pergantiann pihak pengelola dari perusahaan kepada masyarakat perorangan yang berakibat bertambahnya jumlah titik lokasi tempat khusus parkir.

\section{b. Aturan Hukum Tidak Ditegakkan}

Terhadap pengelolaan parkir di Kota Solok baik di tepi jalan umum maupun tempat khusus parkir, pemerintah dan pihak pengelola kurang serius dalam bekerja secara aturan. Hal tersebut, dapat dilihat banyak persoalan parkir yang terjadi dan banyaknya pengaduan masyarakat, pemerintah daerah seolah diam dan bergeming. Pelanggaran yang dilakukan oleh pihak pengelola dibiarkan tanpa pemberian sanksi dan penindakan. Kualitas dan prestasi kerja bukan menjadi suatu ukuran. Kenyataannya, pengalaman kegagalan pihak pengelola bukan menjadi pertimbangan dalam melanjutkan kerja sama di tahun berikutnya, tetapi intervensi pihak yang kuat yakni tim sukses walikota.

\section{c. Prinsip transparansi tidak dijalankan Untuk mewujudkan prinsip transparansi dalam pengelolaan parkir ditandai dengan adanya sistem operasional prosedur (SOP) yang mendukung adanya keterbukaan infirmasi kepada masyarakat. Inisiatif untuk menyusun SOP tidak dimiliki oleh pemerintah kota. Pemerintah cenderung menutup informasi terkait kebijakan dengan}

alasan pertimbangan kerahasian. Terkait dalam hal penetapan harga limit yang digunakan sebagai landasan penetapan nilai kontrak kerjasama, pemerintah memngambil kebijakan secara sepihak tanpa melibatkan pihak swasta maupun masyarakat dalam melakukan uji petik ke lapangan. Padahal keterlibatan masyarakat maupun swasta dalam uji petik semakin meningkatkan kepercayaan pada masyarakat dan meminimalisir adanya kecurigaan kepada pemerintah dalam upaya dengan sengaja meninggikan nilai kontrak tanpa berdasarkan dengan realita dilapangan. Selanjutnya dalam proses pengalihan peran pemerintah kepada swasta, erat kaitannya dengan kebijakan pemerintah dalam menerapkan sistem penunjukan langsung yang terindikasi adanya upaya bagi-bagi proyek kepada tim sukses sebagai motif kepentingan politik balas budi.

\section{d. Tidak efesien dan tidak efektif pengelolaan parkir}

Merosotnya pendapatan restribusi parkir dari tahun ke tahun baik di tepi jalan umum maupun di tempat khusus parkir menandai kinerja kerjasama pengelolaan parkir tidak berjalan sesuai dengan semestinya diharapakan. Ketika kerjasama dikembalikan kepada pihak masyarakat perorangan, kinerja pendapatan restribusi menjadi memburuk sehingga tidak terpenuhi pencapaian target. Terkait kualitas pelayanan dan ketertiban parkir ke masyarakat hasil penelusuran dokumen penelitian Balitbang dan LPPM Unand menjelaskan semakin buruk dan sembrawutnya kinerja pelayanan parkir sejak di kelola oleh masyarakat 
Vol.5, No.1, April 2019

Doi: $10.24198 / \operatorname{cosmogov} . v 2 \mathrm{i} 2 . x x x x x$

perorangan dan ditambah lagi banyaknya pengaduan masyarakat tentang penetapan tarif parkir yang beragam dan jelas melanggar ketentuan tarif yang berlaku.

Tabel 4. 1

Realisasi Pendapatan Parkir Tepi Jalan Umum Kota Solok

\begin{tabular}{|l|l|l|l|c|}
\hline NO & TAHUN & TARGET & REALISASI & KET \\
\hline 1 & 2015 & Rp.656.411.000,00 & Rp.613.695.000,00 & $($ Rp. 42.716.000,00) \\
\hline 2 & 2016 & Rp.663.966.000,00 & Rp.624.316.000,00 & $($ Rp 39.650.000,00) \\
\hline 3 & 2017 & Rp.663.966.000,00 & Rp.315.838.000,00 & $($ Rp 348.128.000,00) \\
\hline
\end{tabular}

Sumber: Olahan dari Laporan Keuangan DPPKA

Kota Solok Tahun 2015, 2016 dan 2017

Tabel 4. 2

Realisasi Pendapatan Parkir Tempat Khusus Parkir Kota Solok

\begin{tabular}{|c|c|c|c|c|}
\hline NO & TAHUN & TARGET & REALISASI & KET \\
\hline 1 & 2015 & $\begin{array}{c}\text { Rp } 730.231 .000, \\
00\end{array}$ & $\begin{array}{c}\mathrm{Rp} \\
732.801 .000,00\end{array}$ & Rp 2.569.000,00 \\
\hline 2 & 2016 & $\begin{array}{c}\text { Rp 821.984.687, } \\
00\end{array}$ & $\begin{array}{c}\mathrm{Rp} \\
838.909 .687,00\end{array}$ & Rp 18.925.000, 00 \\
\hline 3 & 2017 & $\begin{array}{c}\text { Rp 888.302.000, } \\
00\end{array}$ & $\begin{array}{c}\mathrm{Rp} \\
712.000 .000,00\end{array}$ & Rp 176.302.000, 00 \\
\hline
\end{tabular}

Sumber: Olahan dari Laporan Keuangan DPPKA Kota Solok, 2015, 2016 dan 2017

\section{e. Pengelolaan parkir tidak akuntabel. \\ Tidak adanya laporan} pertanggungjawaban pengelolaan parkir oleh pihak pengelola menandai kerjasam tidak terlaksana dengan baik dan disiplin. Pihak mayarakat pengelola cendrung tidak memiliki kemampuan adminsitrasi sehingga penyusunan laporan merupakan suatu beban yang sangat berat ketika ahrus dilaksanakan.

\section{Faktor-Faktor yang Menghambat Keberhasilan Implementasi Kebijakan Kerjasama Pengelolaan Parkir Di Kota Solok.}

Menyangkut hasil penelitian penulis terhadap faktor-faktor yang meyebabkan ketidakberhasilan implementasi kebijakan kerjasama pengelolaan parkir dalam mewujudkan Good Governance pengelolaan parkir di Kota Solok menunjukan adanya kesesuaian dan mendukung pendapat yang dikemukakan oleh Merilee S. Grindle yang dilengkapi denga pendapat Agus Dwiyanto, dengan penjelasan sebagai berikut:

a. Kekuasaan, kepentingan dan strategi aktor yang terlibat.

Akibat kuatnya pola jaringan hubungan kekuasaan yang dimiliki pemerintah dengan warga setempat memunculkan kekuatan bagi warga tempatan untuk mengambil alih kewenangan kerjasama pengelolaan parkir yang dilatarbelakangi berbagai kepentingan Dominasi aktor warga tempatan dilatarbelakangi oleh kepentingan warga dalam memperoleh pekerjaan dan sumber pendapatan yang praktis tanpa dibebani syarat keahlian dan modal yang besar sehingga memunculkan upaya memamfaatkan relasi kekuasaan oleh warga tempatan selaku aktor yang dominan dalam akses untuk mengelola sumber daya parkir. Kedekatan hubungan dengan pejabat daerah akibat dari proses konstelasi politik setelah pelaksanaan pemilihan legislatif dan kepala daerah di Kota Solok. 
Vol.5, No.1, April 2019

Doi: $10.24198 / \operatorname{cosmogov} . v 2 \mathrm{i} 2 . x x x x x$

\section{b. Karakteristik Lembaga dan Penguasa \\ Pemerintah Kota Solok dibawah} kepemimpinan walikota melalui lembaga teknis daerah yang berwenang menangani persoalan parkir memiliki peran penting dan vital dalam setiap kebijakan yang strategis. Pengelolaan sumber daya parkir di Kota Solok rentan dengan kepentingan berbagai pihak baik swasta, masyarakat maupun elitelit politik pemerintahan lainya. Konflik kepentingan menjadi hal yang tidak bisa dihindarkankan dan menjadi perhatian serius pemerintah kota dalam hal penyelesaian. Ketidaktegasan pemerintah dalam menegakan aturan yang dilatarbelakangi pertimbangan politik mengakibatkan tidak adanya tindak lanjut penyelesaiannya pengaduan masyarakat terkait persoalan pelayanan. Banyaknya pengaduan masyarakat pelanggaran yang dilakukan oleh pihak pengelola dibiarkan tanpa pemberian sanksi dan penindakan. Pemerintah daerah seolah diam dan bergeming, kualitas dan prestasi kerja bukan menjadi suatu ukuran, pengalaman kegagalan pihak pengelola bukan menjadi pertimbangan dalam melanjutkan kerja sama di tahun berikutnya, tetapi intervensi pihak yang kuat yakni tim sukses wali kota membuat prosedur normatif tidak dijalankan

\section{c. Ketidakpatuhan dan minimnya daya tanggap pelaksana}

Ketidakberhasilan implementasi kebijakan kerjasama pengelolaan parkir di kota Solok salah satunya disebabkan karena keberadaan pengelola parkir yang ditunjuk tanpa dilatar belakangi dengan kemampuan manajemen yang baik dan penguasaan terhadap peraturan dan hanya bermodalkan kedekatan dengan pimpinan daerah sehingga dalam mengelola parkir, mereka bekerja tanpa memiliki tanggungjawab yang jelas. Sering kali kebijakan atau aturan umum yang diterapkan cendrung dilanggar dengan alasan mengkaji asal usul sosial. Pihak pengelola yang merupakan pemuda atau dalam istilah "preman pasar raya" tidak memiliki pemahaman tentang pelayanan dan tanggung jawab terhadap masyarakat. Dalam pemikiran mereka hanyaterpetik bagaimana upaya meraup pendapatan sebesar-besarnya dengan mudah tanpa memikirkan dampak sosial yang terjadi akibat tindakan yang mereka lakukan.

\section{d. Ketidaktransparanan pengalihan peran pemerintah ke swasta. \\ Implementasi kebijakan kerjasama} pengelolaan parkir dapat terlaksana dengan baik jika di dalam proses pengalihan peran pemerintah ke pihak swasta dilaksanakan secara terbuka kepada masyarakat, mulai dari penetapan harga limit yang diberikan ke pihak pengelola dan keterbukaan mekanisme lelang atau penunjukan pihak swasta sebagai pengelola. Ketidakterbukaan informasi kepada masyarakat mengakibatkan masyarakat sulit untuk terlibat mengawasi proses mekanisme yang terindikasi menyimpang dari aturan sehingga tidak adanya adanya semacam peringatan dini terhadap setiap kebijakanyang dikeluarkan oleh Pemerintah Kota Solok. Hal tersebut dapat dilihat pada proses tidak dilibatkan pihak swasta maupun masyarakat dalam melakukan survey uji petik ke lokasi parkir yang bertujuan menetapkan harga limit yang akan dituang dalam kontrak kerjasama. 
Vol.5, No.1, April 2019

Doi: $10.24198 /$ cosmogov.v2i2.xxxxx

Dalam proses pengalihan peran, sistem kerjasama dilakukan dengan memaksakan mekanisme penunjukan langsung dengan cara memecah objek kegiatan menjadi paket kecil per titik lokasi. Mekanisme penunjukan langsung tersebut memunculkan adanya motif kepentingan politik balas budi terdapat kelompok masyarakat yang berjasa sebagai tim sukses walikota dengan mengatur rekanan atau pihak ketiga yang akan dijadikan pengelola parkir.

\section{e. Ketidakefektifan Kontrol Birokratik dan Politik.}

Masih lemahnya dalam hal kontrol dan pengawasan baik Pemerintah Kota maupn DPRD dan tidak mampu bersikap tegas terhadap penyimpangan yang dilakukan oleh pihak swasta selaku mitra dalam pengelolaan urusan pelayanan parkir menjadi salah satunya penyebab gagalnya implementasi kerjasama pengelolaan parkir dalam mewujudkan Good Governance pengelolaan parkir di Kota Solok. Tidak adanya proses peninjauan kembali prosedur penunjukan langsung lahan parkir yang dilakukan oleh OPD dan evaluasi terhadap sistem penunjukan langsung pengelolaan lahan parkir. Pemerintah melalui inspektorat dinilai tidak tegas dalam melakukan penindakan terhadap tarif yang tidak sesuai dengan aturan, menjamur lahan parkir liar serta tidak terpenuhi realisasi target pendapatan asli daerah dari sector restribusi parkir, sehingga hal tersebut mengakibatkan prinsip efektifitas dalam penegelolaan parkir tidak dapat terwujud.

\section{KESIMPULAN}

Beberapa kesimpulan dapat ditarik dari hasil analisis implementasi kebijakan kerja sama pengelolaan parkir dalam mewujudkan Good Governance Parkir di Kota Solok, yakni:

1. Penerapan prinsip-prinsip Good Governance dalam pengelolaan parkir di kota Solok belum terlaksana dengan maksimal, hal tersebut dikarenakan:

a. Kelompok masyarakat setempat terlalu mendominasi dalam hal kekuasaan dan partisipasinya terhadap pengelolaan parkir terkesan berlawanan dengan aturan hukum akibat memiliki pola hubungan politik dengan penguasa.

b. Masih minimnya akses layanan informasi kepada publik terkait proses pelaksanaan kerja sama terutama dalam pengalihan peran pemerintah kepadan pihak ketiga dan tidak adanya keterlibatan masyarakat dalam proses keputusan atau kebijakan penentuan harga limit.

c. Banyaknya laporan dan pengaduan masyarakat terkait buruknya kinerja pelayanan parkir di Kota Solok serta merosotnya pencapaian target pendapatan restirbusi dari sektor parkir dari tahun ke tahun.

d. Tidak adanya laporan pertanggung jawaban pihak pengelola terhadap kinerjanya baik secara keuangan maupu pelayanan. 
CosmoGov: Jurnal Ilmu Pemerintahan

Vol.5, No.1, April 2019

Doi: 10.24198/cosmogov.v2i2.xxxxx

2. Ketidakberhasilan Implementasi Kebijakan kerja sama pengelolaan parkir di Kota Solok berkaitan dengan beberapa faktor yang mempengaruhi implementasi kebijakan, yakni:

a. Kepentingan, kekuasaan, dan strategi aktor yang terlibat

Hubungan politik pimpinan daerah dengan pihak pengelola sebagai tim sukses membentuk mata rantai kekuasaan yang absolut. Akibatnya kebijakan orentasi pembangunan dikotomi oleh kepentingan kekuasaan. Kepentingan politik menjadi dominan dalam pelaksanaan kerja sama pengelolaan parkir di kota solok, bari dari sisi Pemerintah Kota maupun masyarakat selaku pihak pengelola. Pola kekuasaan yang diterapkan dapat dilihat dari;

1) Akses terhadap penguasa.

Dalam pelaksanaan kerja sama pengelolaan parkir di kota Solok, ditemukan bahwa pihak pengelola parkir lebih menonjolkan akses identitas dan relasi sosial. Dapat dilihat dari bagaimana pihak pengelola yang tidak memiliki modal, teknologi, tenaga kerja, pengetahuan dapat ikut terlibat dalam pengelolaan parkir di Kota Solok.

2) Resistensi terhadap kebijakan

Kerja sama pengelolaan parkir di Kota Solok tidak mempertimbangkan situasi dan kondisi sosial masyarakat lokal. Aktivitas pengelolaan parkir mayoritas digeluti oleh
ISSN 2442-5958

E-ISSN 2540-8674

masyarakat/pemuda pasar yang terbiasa dengan budaya prilaku premanisme serta diperkuat dengan adanya ikatan primordialisme dengan pejabat lokal, sehingga kelompok masyarakat tersebut cendrung melakukan perlawanan terhadap setiap kebijakan pemerintah daerah.

b. Karakteristik Lembaga dan Penguasa Konflik kepentingan dalam pengelolaan parkir menjadi persoalan yang tidak pernah selesai. Ketidaktegasan pemerintah dalam menegakan aturan yang dilatarbelakangi pertimbangan politik mengakibatkan tidak adanya tindak lanjut penyelesaiannya pengaduan masyarakat terkait persoalan pelayanan parkir yang berujung gagalnya implementasi kerjasama pengelolaan parkir dalam mewujudkan Good Governance pengelolaan parkir di kota Solok.

c. Ketidakpatuhan dan minimya daya tanggap pelaksana

Keberadaan pengelola parkir yang ditunjuk tanpa dilatar belakangi dengan kemampuan manajemen yang baik dan penguasaan terhadap peraturan dan hanya bermodalkan kedekatan dengan pimpinan daerah sehingga dalam mengelola parkir, mereka bekerja tanpa memiliki tanggungjawab yang jelas. Sering kali kebijakan atau aturan umum yang diterapkan cendrung dilanggar dengan alasan mengkaji asal usul sosial. 
Vol.5, No.1, April 2019

Doi: 10.24198/cosmogov.v2i2.xxxxx

d. Ketidaktransparanan pengalihan peran pemerintah ke swasta

Dalam proses pengalihan tersebut terlihat proses transparansi belum diterapkan, hal ini dapat dilihat dari sistem kerjasama dilakukan adalah memaksakan mekanisme penunjukan langsung dengan cara memecah objek kegiatan menjadi paket kecil per titik lokasi. Mekanisme penunjukan langsung tersebut memunculkan adanya motif kepentingan politik balas budi terdapat kelompok masyarakat yang berjasa sebagai tim sukses walikota dengan mengatur rekanan atau pihak ketiga yang akan dijadikan pengelola parkir.

e. Ketidakefektifan kontrol Birokratik dan Politik

Dalam hal ini pemerintah daerah Kota Solok maupun DPRD masih lemah dalam hal kontrol dan pengawasan dan tidak mampu bersikap tegas serta terkesan adanya pembiaran terhadap penyimpangan yang dilakukan oleh pihak swasta selaku mitra dalam pengelolaan urusan pelayanan parkir.

\section{DAFTAR PUSTAKA}

Lembaga Administrasi Negara, 2000, Akuntabilitas dan Good Governance, Modul Sosialisasi Sistem Akuntabilitas Kinerja Instansi Pemerintah (AKIP), Jakarta.

Dwiyanto, Agus. (1996). Kemitraan Pemerintah - Swasta dan Relevansi Terhadap Reformasi Administrasi
Negara, JKAP Vol.I, Nomor I, Program Magister Administrasi

Mulyani, Sri. (2017). Integrasi Riset dan Pembelajaran dalam Studi Administrasi Negara. Journal of Public Affairs and Administrative Science.

Balitbang Kota Solok, LPPM Unand. (2017). Kajian Penataan Kembali Lokasi dan Sistem Pakir Kawasan Pasar Raya Kota Solok, Solok, Program Balitbang Kota Solok.

Perwako Solok No.7 tahun 2105 tentang kerjasama pengelolaan parkir di Tepi Jalan Umum.

Perwako Solok No.8 tahun 2105 tentang kerjasama pengelolaan parkir di Tempat Khusus Parkir.

kritisnews.com tanggal 19 desember 2016, Tarif Parkir Langgar Perda, DPRD Solok desak Wako Tindak Tegas Pengelola 